\title{
The vision and interiorization of leisure and free time of post-degree students
}

\section{La visión e interiorización del ocio y el tiempo libre en estudiantes de postgrado}

\author{
YAÑEZ-FLORES, Sara Margarita†*, HERNÁNDEZ-CUETO, Jaquelina Lizet, SALINAS-AGUIRRE, \\ María del Consuelo and SOLÍS-SOLÍS, Alma Verena
}

Facultad de Ciencia, Educación y Humanidades de la Universidad Autónoma de Coahuila, Campus Saltillo.

ID $1^{\text {st }}$ Author: Sara Margarita, Yañez-Flores / ORC ID: 0000-0002-4750-4244, Researcher ID Thomson: S-9231-2018, CVU CONACYT ID: 352125 .

ID $1^{\text {st }}$ Coauthor: Jaquelina Lizet, Hernández-Cueto / ORC ID: 0000-0002- 3728- 7434, Researcher ID Thomson: S-85882018, CVU CONACYT ID: 322702

ID $2^{\text {nd }}$ Coauthor: María del Consuelo, Salinas-Aguirre / ORC ID: 0000-0002-6542-1813, Researcher ID Thomson: S-92442018, CVU CONACYT ID: 615335

ID $3^{\text {rd }}$ Coauthor: Alma Verena, Solís-Solís / ORC ID: 0000-0002-0274-2388, Researcher ID Thomson: S-7919-2018, CVU CONACYT ID: 864488

DOI: $10.35429 / J S E T M .2019 .4 .3 .10 .19$

Received January 27, 2019; Accepted June 18, 2019

\begin{abstract}
Leisure and free time are a part of human beings' life, and perhaps neither how nor why is thought of. In leisure, activities are individual and obligation free; free time activities, although can be chosen whether to do them or not, are linked to social pressures and included in the legislation and as universal human rights: Recreation, amusement and rest. The objective of the article is to analyze the way in which the post-degree students visualize and incorporate the leisure and free time in their everyday life. The used method is quantitative, explorational-descriptive, and transversal. The article contributes demonstrating the subjective wealth that impregnates the leisure forms and free time activities into the way each of the individuals do things, think, say, and spend time in their educational, social, and work related relationships and interrelationships. The questionnaire was answered by 70 post-degree students -53 women and 17 men- most of them working. Some female students spend $15 \%$ of their week in free time activities and $27.5 \%$ to leisure; in both activities men said to spend $27 \%$ of their week. Only 16 women and six men consider free time as a fundamental human right.
\end{abstract}

Leisure, Free time, Gender

\begin{abstract}
Resumen
El ocio y el tiempo libre forman parte de los seres humanos y quizá, ni se repara en qué y cómo los utilizan. En el ocio, las actividades son individuales y sin obligación; las actividades en el tiempo libre, aunque con libertad de hacerlas o no, están condicionadas por presiones sociales e incluidas en la legislación y como derechos universales: recreación, esparcimiento y descanso. El objetivo del artículo, es analizar las formas en que los/las estudiantes de postgrado visualizan e incorporan el ocio y el tiempo libre en su cotidianidad. El abordaje metodológico es cuantitativo, exploratorio-descriptivo y transversal. La contribución del estudio, es mostrar la riqueza subjetiva que impregna las formas del ocio y el tiempo libre en el hacer, pensar, decir, convivir de cada uno de los individuos en sus relaciones e interrelaciones educativas, sociales y laborales. Se aplicó el instrumento a 70 estudiantes de postgrado -53 mujeres y 17 hombres - quienes en su mayoría trabajan. Algunas estudiantes dedican 15\% semanal al tiempo libre y en promedio $27.5 \%$ al ocio; los hombres, en ambas, dedican semanalmente un promedio de $27 \%$; solamente 16 mujeres/ 6 hombres consideran al tiempo libre como un derecho humano fundamental.
\end{abstract}

Ocio, Tiempo libre, Género

Citation: YAÑEZ-FLORES, Sara Margarita, HERNÁNDEZ-CUETO, Jaquelina Lizet, SALINAS-AGUIRRE, María del Consuelo and SOLÍS-SOLÍS, Alma Verena. The vision and interiorization of leisure and free time of post-degree students. Journal Schools of economic Thought and Methology. 2019. 3-4: 10-19.

\footnotetext{
* Correspondence to Author (email: a_munoz_r@hotmail.com)

$\dagger$ Researcher contributing as first author.
} 


\section{Introduction}

It is not from this article to delimit or reach a consensus of what leisure $(\mathrm{Oc})$ and leisure time (Tl) is; Its objective is to analyze the ways in which postgraduate students visualize and incorporate leisure and free time in their daily lives. The historical journey that takes place on these two concepts and the way in which the legislation contemplates them, allows us to realize that there is no consensus on the possible delimitations of both.

In the Introduction section, the importance and feasibility of the study is explained; while presenting the question and objectives that guide the development of the study presented.

In the section that refers to the Perspective of leisure and free time, it deals with what refers to leisure in the historical future; observing that this has presented different features of acceptance: the Greek ideal of contemplation; with the Romans leisure became activities for the elite and "rest" for the people; subsequently, leisure assumes negative connotations and is suppressed because it is considered unproductive (idleness).

In more recent times, leisure $(\mathrm{Oc})$ is related to free time ( $\mathrm{Tl}$ ); establishing that $\mathrm{Tl}$ are activities outside of employment, work, study and Oc is not affected by any of these activities. Thus, $\mathrm{Tl}$ is accounted for through units of measure, the Oc, for its eminently individual characteristic, is considered qualitative.

Likewise, it is exposed with respect to the way in which the laws in Mexico and universal rights contemplate leisure and free time, it is through the terms recreation and recreation that punctuates the right that children, youth and adults have to these activities ; activities that are referred to as the right to sport, to culture as a way to strengthen the family nucleus, the physical and mental health of its members, as well as a way of retraining the offending minors.

The concept of "rest" appears as a right considered in art. 123 of the Political Constitution of Mexico of 1917 and in the Universal Declaration of Human Rights in 1948.
An interesting point within Mexican legislation and the fundamental rights of the human being is the incorporation of gender equality in terms of rest, recreation and recreation, both inside and outside the work area.

The Methodology section indicates that the type of research is quantitative, exploratorydescriptive and transversal; 20 simple variables distributed in two axis variables are used: leisure and free time and analyzed from a gender perspective.

For the description of the population, the age variable is used, the weekly percentage that participants assign to $\mathrm{Tl}$ and Oc. As contextualizing variables of the study, the continuation or not of studies and the reasons for this decision are considered.

What alludes to the population / sample, the study analyzes the opinions of masters and postgraduate students, through an incidental sampling.

In the Results section, the description of the population and the exploration of the variables that, on leisure and free time, are described are presented.

In the Conclusions section, the question and the achievement of the objectives proposed in this study are answered.

\section{Justification}

Leisure (Oc) and free time (Tl), are factors of social integration and from a humanistic perspective, it is necessary to consider them in the integral formation of students, regardless of their educational level or age.

It is necessary for this, to resize what each one contributes in the development of individuals, both from informal and formal education / learning. Hence the importance of knowing how women and men visualize and incorporate leisure and free time into their daily lives. The study is viable since there are resources, times and a population / sample that, due to their training characteristics, support the development of studies that allow us to know the opinions related to relations and socioeducational and labor reality. 


\section{Problem}

The research starts from the question: How do the master's and doctoral students of the Faculty of Science, Education and Humanities of the Autonomous University of Coahuila visualize and incorporate leisure and free time?

\section{Overall objective}

Analyze the ways in which postgraduate students visualize and incorporate leisure and free time in their daily lives.

\section{Specific objectives}

Describe the sociodemographic characteristics of the participating population.

Explore the leisure and free time variables that describe the vision and incorporation of leisure and free time in the students' daily life.

\section{Leisure and free time}

\section{Perspectives}

The meanings, scope and challenges of these concepts depend very much on the social, labor, economic and political reality from which they are framed. The Greek's perspective, the skholé (leisure), was the antithesis of doing nothing; It was a state of peace and creative contemplation. However, having time for himself was exclusive to the elite, and work for slaves.

The Roman otium, refers to the free time that was given after work and then return to work. The otium is intellectual and, according to the economic and political context, this introduces new connotations: mass leisure. This concept means unemployment and fun for the people; activities despised by elites but at the same time encouraged them.

For Munné (2010), in the Greeks "(...) work is a means and leisure is an end"; while for the Romans "(...) leisure becomes a means and work, the end."
Subsequently, ostensible leisure appears, that is to say, consumption, extravagance and therefore exteriorization. Leisure becomes evidence of power, wealth, as opposed to working time considered servility and therefore unworthy. (Munné, 2010; pp. 40-47).

This is how leisure is acquiring negative connotations, for example the saying, "idleness as the mother of all vices."

In this historical development, leisure is a wasted time, it is condemned above all in the rise of industrialism. It is necessary to consider that industrialization, in its beginnings does not reduce, on the contrary it increases the working hours that, after legislative reforms, result in the time of full individual disposition; Regarding modern leisure, Munné (2010) indicates that:

Now time is subtracted from habitual and daily work, not because the specific content of that time is valued, but because the work has been devalued. Consequently, what matters is non-work; Not directly leisure. The essential value happens to reside less in the qualitative aspects of leisure, referring to the content of the phenomenon, than in the quantitative ones related to time. (pp. 49-50)

Leisure, presents its problems of definition and univocal acceptance of the term; but in a general way Gomes and Elizalde (2009) point out that, "(...) leisure can both express ways of reinforcing injustices, alienations and social oppressions, and on the contrary represent a possibility of freedom and dignification of the human condition." (p. 261)

The proposal of Cuenca, Bayón and Madariaga (s / f), refers to some proposals related to leisure, such as:

a) Socialization, which develops emotional ties, social cohesion and community integration, while allowing the introduction of individuals in "organizations, networks and social contacts of great importance."

b) Solidarity, which refers to voluntary aid activities; activities that these authors call "superior leisure" and therefore selfish. 
c) Natural environment, which implies the choice of leisure experiences that do not negatively impact it.

d) Consumption, although some leisure activities require financial disbursements, should try to privilege the human over it.

e) Innovation, linked to the idea of "experiences and the search for quality of life of citizens"; experiences that motivate other ways of understanding and socializing leisure.

In this regard, Gomes and Elizalde (2009) comment that:

(...) the qualities planned in the moments of leisure - such as satisfaction, fulfillment, recognition, autonomy, freedom, creativity and criticality - will have greater opportunities to materialize at work from the moment we develop the battle on a single front: that of "work -andleisure ". (p. 262)

What alludes to free time, the common thread is the social time that the individual devotes to different activities. Munné (2010), evidences the contradictions presented by the authors when trying to define what is the Tl and, where, in addition, certain positions that refer to Oc. Munée (2010) identifies them as "five free times":

a) The one after work.

b) The one that is free from everyday needs and obligations.

c) Free from daily needs and obligations, but it is used in what the person wants.

d) All groups operate by subtraction which supports the latter part of the above definition, and says Munne (2010), Stanley Parker (1971) indicates that "is what the entertainment for most people" and e ). Part of the time devoted to the physical and intellectual development of man as an end in himself; clarifying that this last position focuses on the teleological or axiological nature of the activity carried out. (pp. 54-57)
As can be seen, there is a dichotomy between leisure time. Leisure time is generally associated with-no-work-, that is, with the time you have after working as a way to make a living and that is part of the obligations. However, it is emphasized that other unpaid, but fundamental obligations are also made in the $\mathrm{Tl}$. In the free time, in addition to the professional-paid obligations and the social-fundamental obligations, there are other activities that are carried out in free time such as living with the family, playing sports, seeking employment. Sarrate (2009), makes a distinction between the two concepts:

Free time is a condition for leisure, but not the only and sufficient one, as can be seen from the two main categories that Quintana points out (2004: 10-11): the time committed to primary human needs and labor obligations and family, and the free time that includes: utilitarian time and released.

The utility would then be the one assigned to obligations, even if they are free to do so, and the time released "is not subject to any commitment". Further on he points out that free time is "the available space, in a double dimension of" free of "and" free "for" that we can use enrichingly or wastefully ". The same author indicates that $\mathrm{Tl}$ becomes leisure when it is used to "grow as people." (Sarrate 2009, pp. $52-54)$

Neulinger (1974), quoted in Peralta (2012) " (...) clarified that it was not a problem of" free time "but a problem of what was done and experienced in that free time, that is, a problem properly of leisure". (p.2)

Free time as such is subject to the pressures that the individual or social groups have after work; "Freedom" although socially and legally conquered, is far from being the ideal even though, apparently, less work is done today and this, in an ideal, could be a time of personal development. In this order of ideas, Munné (2010) makes an approximation to the definition of free time, "(...) consists of a way of giving yourself social time, personally felt as free and by which man is conditioned to compensate himself, and in last term affirm individually and socially. He ends by saying "(...) freedom for freedom." (p. 205) 
In this regard, Gomes and Elizalde (2009) comment that Souza Junior (2000) indicates that, "It is a period in which the individual is momentarily free, but this freedom may be apparent and limited." (p, 255). It is necessary not to forget that this "freedom" depends a lot on the experiences and social, labor, economic and political possibilities of [the] individuals; it seems that "freedom" is a privilege, rather than a choice.

The revision of the definition of leisure in the RAE Dictionary (2014) coincides with what is indicated by Gomes and Elizalde (2009), "(...) we can observe how leisure is related to free time, rest, recreation and with the playful." (p. 263).

Munné (2009), and Gomes and Elizalde (2009) agree that " (...) we must not forget that the word with which many languages designate leisure - fill in Catalan, loisir in French [in France is the most used word for define leisure as enjoyment of free time to rest, have fun or develop the human being], leisure in English, etc. - etymologically means being lawful or allowed to do something (from Latin: licere); Gomes and Elizalde (2009) add that these terms also mean, from their etymology: to be allowed, to be able, to be entitled. Likewise, the term recreation and recreation is related to the French word loisir; this gives the guideline to link what is related to current legislation in Mexico and in the global context.

\section{Leisure and free time legislation}

According to Mora (s / f), during the nineteenth and twentieth centuries, and as a result of the workers' struggles, the concept of rest [as a right] begins to relate, above all, to working hours; right that was recognized in article 123 of the Mexican Constitution (1917) and in the Universal Declaration of Human Rights (1948). (p. 284)

As of 1950, the term recreation is generalized, after the recognition of free time as a right; it is at that time that it begins to be recognized that "(...) recreational activities enable the expression of new needs and capacities"; At that same time the term recreation is associated with recreation recognized as an international right - understood as "the set of activities that fill leisure time".
In accordance with the foregoing, the right to recreation - in a democratic State - "(...) is to voluntarily dedicate - after having been released from their obligations - to rest, have fun, develop their training or participate in the social life of their community". Following the ideas of Mora (s / f) in the concept of recreation, three functions of the life of an individual are developed, such as:

a). Regenerating physical and psychological rest for the person, necessary to recover from fatigue caused by working time or obligations.

b). The compensatory fun of routines, the monotony of daily life, a liberating and playful attitude.

c). Development-creation of ideas, exercise of creativity, innovation capacity.

The author comments that within a state of democratic law, there are five keys to the advancement of the democratic state in Latin America (Caprpizo, 2009); only the one that alludes to the subject studied stands out, which indicates that "(...) The social character that refers to the quality of life of the inhabitants taking into account satisfiers such as: food, education, health protection, work, housing and recreation ". (Mora s / f, p. 285)

In Article 4 of the Constitution, several of the rights of which, for purposes of this study, are related to gender equality, the freedom of the number of children and the way of spreading them; in addition to the right to cultural property and creative freedom. In that same constitutional article, the right to physical culture and the practice of sports is recognized and, among other equally fundamental rights, the right to a healthy environment for its development and well-being (Political Constitution of the United Mexican States, 2015 ). The above is coincident with Touraine (1974) who argues that: (...) leisures, like any activity outside of strict work, encompass most of the cultural features of a society, such as religious life, games, political activity or sport. Free time is a time without paid obligations and is only a problem when there is no traditional forecast of culture to make use of it. (Miranda, 2006; p.302) 
The Federal Labor Law (CDHCU, 2019) specifies the conditions under which workers work in decent or decent work, rest days and vacations, and substantive equality: nondiscrimination against women and recognizes the same opportunities from the biological, social and cultural differences of women and men. Even in the General Health Law (CD HCU, 2018) it is specified that the protection of health has, among other purposes: "The physical and mental well-being of the person, to contribute to the full exercise of their abilities (Reformed DOF 14 -01-2013) and The prolongation and improvement of the quality of human life "(Art2 ${ }^{\circ}$ ). In this same law, reference is made to the promotion of recreational, sociocultural and educational activities that contribute to mental health (Art.72 and 73).

In the Universal Declaration of Human Rights (1948), rights such as freedom of opinion, beliefs and assembly are indicated, as well as social security and those indispensable for the dignity and free development of personality (economic, social rights and cultural). And, the right to rest, to enjoy leisure time, to a reasonable limitation of the duration of work and to paid periodic vacations (UN, 1948: Art. 18-27).

Finally, not conclusively, in the IberoAmerican Convention on the Rights of Young People (OIJ, 2008), they include the fundamental rights referred to in previous paragraphs, but specifically to young people between 15 and 24 years of age. However, as revised, the legislation includes from childhood to old age.

In this journey of legal and human rights in recreation and recreation, as promoters of healthy personality development, it is evident that leisure and free time are socially, educationally and legally contemplated; However, the evidence in Mexican reality is not promising.

\section{Methodology}

\section{Type of investigation}

The research The vision and internalization of leisure and free time in postgraduate students is quantitative, exploratory-descriptive and transversal (September - November 2018).
In addition, the results are explored and described from the perspective of men and women, since this perspective is considered to better evidence the interiorization of leisure and free time in the daily lives of the participating students.

\section{Variables}

The Leisure and Free time axis variables are integrated by 10 simple variables each. In the study, simple variables present conditions, derived from documentary reviews, which allow an analysis of the activities that students highlight and associate with leisure and leisure time. Table 1 shows the variables that indicate the incorporation of leisure activities (i.e. the freedom to decide, to do) and indicate the eminently individual impact on personal development.

\begin{tabular}{|l|l|}
\multicolumn{1}{|c|}{ Variables } & Condition \\
\hline Project development on own initiative & \\
\cline { 1 - 1 } Personal development activities & \\
\cline { 1 - 1 } Learn to enjoy the TL & \\
\cline { 1 - 1 } Perform activities for the benefit of the community & \\
\cline { 1 - 1 } Moments of creative freedom & Individual \\
Time for oneself outside of anything that means work & and Social \\
\cline { 1 - 1 } Learn to invest money & Pressure \\
\cline { 1 - 1 } Reflection on the future as a professional & \\
\hline Know the legal conditions regarding hiring and salaries & \\
\hline Perform academic assignments &
\end{tabular}

Table 1 Leisure and its conditions

Source: (Own elaboration, 2018)

The conditions that refer to the individual and social pressure, refer to those activities that, although the individual gives or has the freedom to do so, have features that indicate a certain social pressure (ie social level, work and / or educational activities) to perform them .

In addition, demographic variables are used: gender and age; Likewise, contextualizing variables such as the continuation of studies and the reasons for continuing or not are incorporated.

The reasons also present conditions, for example personal improvement is individual; The job opportunities are of social pressure and the needs of the study area itself, of individual type and social pressure. The reasons for continuing or not studying are part of the current moment in which one lives, where the continuation of them implies better salaries, benefits: job opportunities. 
Table 2 shows variables related to leisure time and, in addition, identifies those that require the status of legal and human rights, in addition to individual conditions and social pressure. In that same, Table 2, variables are located that, although in leisure, are associated with leisure.

\begin{tabular}{|c|c|}
\hline Variables & Condition \\
\hline Mandatory rest times within work activities & \multirow[t]{3}{*}{ Rights } \\
\hline Fundamental human rights & \\
\hline Rest spaces that are allocated during education & \\
\hline The freedom to do anything but work & \multirow[t]{3}{*}{ Individual } \\
\hline Being happy, motivated people & \\
\hline $\begin{array}{l}\text { The personal decision to rest without } \\
\text { deteriorating other productive activities }\end{array}$ & \\
\hline Sports practices as a way to stay active & \multirow{4}{*}{$\begin{array}{l}\text { Individual } \\
\text { and Social } \\
\text { Pressure }\end{array}$} \\
\hline Wasting time in social media care & \\
\hline $\begin{array}{l}\text { Strengthening interpersonal relationships as a } \\
\text { possibility of entry into the labour market }\end{array}$ & \\
\hline $\begin{array}{l}\text { The search for complementary work to } \\
\text { vocational training }\end{array}$ & \\
\hline
\end{tabular}

Table 2 Tiempo libre y sus condiciones Source: (Elaboración propia, 2018)

In addition, the weekly percentages assigned to leisure and leisure time are incorporated by students. All the variables used in this study are analyzed from frequencies and percentages, since it is considered that as an exploratory-descriptive study can lead to deepening and opening lines of research.

\section{Sample}

Sampling is incidental or convenience not probabilistic; in this type of sampling the researchers depended on the authorization of school addresses, teachers to allow the application of surveys and the willingness of students to access the response of the instrument. The requirements were to be active students of the program and to achieve the minimum application of between 50 or 60 students; for this study, it was possible that 70 master's and doctoral students in Education Sciences agreed to answer the instrument freely and voluntarily.

\section{Results}

\section{Demographic and socio-educational description}

Of the 70 postgraduate students, 53 are women, 40 of whom study master's and 12 study doctoral; while of the 17 men, 13 are master's degrees and four PhD's, indicating that the majority work.
Their ages in both men and women range from 24 to 35 years of age. Although with a lower percentage, ages between 45 and 63 years are identified. With regard to the possibility of further study of 51 women and 15 men responded in the affirmative.

The reasons that drive them to continue their studies, in $56.60 \%$ of women is by personal improvement (individual/leisure); $28.30 \%$ for the possibilities that the study gives in job opportunities (individual/external pressure/free time) and $11.32 \%$ for the needs of the study area (individual and social pressure). In the case of men $35.39 \%$ indicates that both by overcoming and by opportunities, respectively.

\section{Time for leisure and leisure}

A low percentage of women gives $70 \%$ weekly at both times (represents approximately four days a week); it also indicates that a maximum of $15 \%$ weekly is used for free time (Table 3 ).

\begin{tabular}{|r|r|r|r|r|r|} 
\%Leisure & Fr & \multicolumn{1}{c}{$\%$} & \% Free time & \multicolumn{1}{|c|}{$\mathbf{F r}$} & \multicolumn{1}{c|}{$\%$} \\
\hline $20-35$ & 20 & 37.74 & $0-15$ & 20 & 37.74 \\
\hline $0-18$ & 15 & 28.30 & $20-30$ & 19 & 35.85 \\
\hline $40-50$ & 5 & 9.43 & $40-50$ & 5 & 9.43 \\
\hline 70 & 2 & 3.77 & 70 & 2 & 3.77 \\
\hline
\end{tabular}

Table 3 time allocation: women Source: (Own Elaboration, 2019)

Of the 17 men, Table 4, the highest percentage are located in the weekly allocation of 20 to $33 \%$ to Oc and free time (it would represent approximately a maximum day 2 per week).

\begin{tabular}{|l|l|l|l|l|l|}
\hline \multicolumn{1}{|c}{ \%Leisure } & \multicolumn{1}{c|}{ Fr } & \multicolumn{1}{c|}{ \% } & \multicolumn{1}{c|}{ \%ree time } & \multicolumn{1}{c|}{ Fr } & \% \\
\hline $20-33$ & 7 & 41.18 & $20-33$ & 6 & 35.29 \\
\hline $70-80$ & 4 & 23.53 & $0-12$ & 4 & 25.53 \\
\hline 10 a 15 & 2 & 11.76 & $60-70$ & 2 & 11.76 \\
\hline
\end{tabular}

Table 4 Time allocation: men

Source: (own-making, 2019)

Only four students assign 70 to $80 \%$ of $\mathrm{Tl}$ per week (on average, five days a week).

\section{Leisure and leisure: vision and incorporation}

The presence of various opinion groups enriches the perspective of women and men on the variables analyzed and evidences the subjectivity in how $\mathrm{Oc}$ and $\mathrm{Tl}$ are incorporated into their daily lives. 
Likewise, through the conditions (rights, individual, individual and social pressure) it allows to clarify the way in which men and women move in individual freedom or in freedom limited by educational, social and labor conditions. Table 5 shows activities, albeit with a small percentage, such as the moments to develop as a person and make it possible to develop your own projects; Tl is also enjoyed and in leisure it is used for the benefit of the community. Activities that reflect the individual status of the same.

\begin{tabular}{|l|c|c|}
\multicolumn{1}{|c|}{$\mathbf{n = 5 3}$} & $\mathbf{F r}$ & $\mathbf{\%}$ \\
\hline Developing projects on their own initiative & 18 & 33.95 \\
\hline Personal development activities & 16 & 30.19 \\
\hline Learn to enjoy TL & 16 & 30.19 \\
\hline $\begin{array}{l}\text { Conduct activities for the benefit of the } \\
\text { community }\end{array}$ & 15 & 28.30 \\
\hline Moments of creative freedom & 15 & 28.30 \\
\hline $\begin{array}{l}\text { Time for yourself out of anything that means } \\
\text { work }\end{array}$ & 14 & 26.42 \\
\hline Learning to invest money & 14 & 26.42 \\
\hline Reflection on the future as a professional & 13 & 24.53 \\
\hline $\begin{array}{l}\text { Know the legal conditions regarding hiring } \\
\text { and wages }\end{array}$ & 12 & 22.64 \\
\hline Performing academic tasks & 12 & 22.64 \\
\hline
\end{tabular}

Table 5 Leisure: vision and internalization of women Source: (own-making, 2019)

Some of the women incorporate individual conditions and social pressure, such as reflection on their future and being aware of legal issues related to the work area. What alludes to free time, Table 6, highlights variables with individual condition and social pressure, which are not fully considered as a way to strengthen interpersonal networks as a means to enter the productive sector, or apparently dedicate it to review social networks (Facebook, Instagram).

\begin{tabular}{|l|r|c|}
\hline \multicolumn{1}{|c|}{ Variables } & \multicolumn{2}{c|}{$\mathbf{F 3}$} \\
\hline The freedom to do any & 25 & 47.17 \\
\hline thing other than work & 25 & 47.17 \\
\hline Be happy and motivated people & 20 & 37.74 \\
\hline $\begin{array}{l}\text { The personal decision to rest without } \\
\text { deterioration of other productive activities }\end{array}$ & 20 & 37.74 \\
\hline Sports practices like & 19 & 35.85 \\
\hline way of staying active & 16 & 30.19 \\
\hline Mandatory rest times within work activities & 15 & 28.30 \\
\hline Human rights & 14 & 26.42 \\
\hline fundamental & 13 & 24.53 \\
\hline $\begin{array}{l}\text { Rest spaces that are assigned during } \\
\text { academic training }\end{array}$ & 12 & 22.64 \\
\hline
\end{tabular}

Table 6 Free time: vision and internalization of Women Source: (own elaboration 2019)
But if they perceive it as the freedom to perform any activity, less work, similar to the results of leisure. Likewise, leisure time is perceived as freedom to be happy people, perform sports activities and as a personal decision of rest and as a rest in accordance with the provisions of the law. Only 16 women out of 53 identify it as a fundamental human right (Table 6).

\begin{tabular}{|l|r|r|}
\multicolumn{1}{c}{ Variables } \\
\multicolumn{1}{|c|}{ Fr } & \multicolumn{1}{c|}{$\%$} \\
\hline Personal development activities & 9 & 52.93 \\
\hline Perform academic assignments & 8 & 47.05 \\
\hline $\begin{array}{l}\text { Perform activities for the benefit of the } \\
\text { community }\end{array}$ & 8 & 47.05 \\
\hline Moments of creative freedom & 7 & 41.17 \\
\hline Time for oneself outside & 7 & 41.17 \\
\hline of anything that means work & 7 & 41.17 \\
\hline Learn to invest money & 5 & 29.41 \\
\hline Project development on own initiative & 5 & 29.41 \\
\hline Learn to enjoy the TL & 5 & 29.41 \\
\hline Reflection on the future as a professional & 5 & 29.41 \\
\hline
\end{tabular}

Table 7 Leisure: vision and internalization of men Source: (own elaboration 2019)

It stands out from Table 7, which students identify leisure as part of their personal development (individual conditions), moments that are used to perform academic tasks (individual and external pressure) and as support for the community (individual). Also, in Table 7, there are percentages that indicate that leisure is considered as creative freedom and personal choice, which is not work. There are also percentages that indicate that leisure is considered as creative freedom and personal choice, which is not work. In free time, Table 8, men say they perceive it as the freedom of choice of non-work activities.

\begin{tabular}{|l|r|r|}
\multicolumn{1}{|c|}{ Variables } \\
\multicolumn{1}{|c|}{ Fr } & \multicolumn{1}{c|}{$\%$} \\
\hline The freedom to do any & 10 & 58.82 \\
\hline thing other than work & 7 & 41.17 \\
\hline $\begin{array}{l}\text { The strengthening of interpersonal } \\
\text { relationships }\end{array}$ & 7 & 41.17 \\
\hline $\begin{array}{l}\text { as a possibility of entering the labor } \\
\text { market }\end{array}$ & 7 & 41.17 \\
\hline Be happy people & 6 & 35.29 \\
\hline and motivated & 6 & 35.29 \\
\hline Wasting time on attention & 5 & 29.41 \\
\hline to social networks & 5 & 29.41 \\
\hline Human rights & 5 & 29.41 \\
\hline fundamental & 5 & 29.41 \\
\hline
\end{tabular}

Table 8 Free time: vision and internalization of men Source: (own elaboration 2019) 
Unlike women, men visualize leisure time as a possibility of entering the labor market through interpersonal relationships and also invest that time in attention to social networks (individual and social pressure). Only 5 men of 17 consider leisure time as a rest after work activities contemplated by law.

\section{Conclusions and discussion}

Leisure and free time have been and continue to be concepts in constant debate. In recent times both concepts are being revalued thanks, among other equally important issues, to the achievements of workers in the field of rest and to consider them as fundamental human rights; hence, they are contemplated as rights in the Mexican Constitution since 1917.

The majority of women and men considered continuing to study; in the case of women, the predominant motive was for personal improvement than according to the conditions, this motive is more based on personal decisions and, primarily, refers to leisure. Unlike men whose motives refer on the one hand to a personal decision (overcoming) but also for social pressures (job opportunities).

The vision and internalization of leisure, although in a low percentage, coincides with what Quintana (2004) points out, cited by Sarrate (2009), points out that "Leisure time is a condition for leisure, but not the only and sufficient one" ; that is to say, leisure being inherent to the human being is not subject to rules or conditions external to it; It is part of the "liberated time that is not subject to any commitment". (Sarrate, 2009) In Mora (s / f) it is observed that recreation and recreation are concepts associated with free time, since it is linked on the one hand to rest that leads to "liberating and playful attitude"; time in which development, creation and innovation can be presented. Activities that refer to leisure, precisely within free time / rest. In this regard, some women on average dedicate to leisure between one or two days a week $(27.5 \%$ weekly), coinciding with the activities they indicated, for example, the development of their own projects that, according to the theory consulted, refers to the development and dignification of the person and also enjoy free time.
What refers to free time, women dedicate one day a week (15\% weekly) which is hypothetically the day that by law (Art. 69 of the LFT, CDHCU, 2019) is stipulated for rest; On this day (assigned percentage) the students exercise their freedom when freeing themselves from work, therefore they are happy people who are dedicated to do what they like without deterioration of other activities and, among other issues, perform sports activities (Mora, s / f).

For their part, men dedicate an average of $26.5 \%$ per week to leisure and free time (mostly), which would be equivalent to approximately one and a half days in both activities; what alludes to leisure students said they dedicate it to personal issues, but also to the accomplishment of academic tasks and help or support the community (only the most representative frequencies / percentages are highlighted). When it comes to leisure, men, although they dedicate it to issues that are not work, use it to strengthen interpersonal relationships as a means of getting work. Precisely Cuenca, Bayón and Madariaga (s / f) indicate that socialization activities are also carried out at leisure: social cohesion and community integration and enable the introduction of individuals into "organizations, networks and social contacts of great importance and solidarity". Remembering that the free time that, although regulated by socio-economic conditions, is also conditioned and even are socio-labor achievements reflected in Mexican legislation (CDHCU, 2019).

However, in the exploration of leisure variables, the opinion of the 53 women is diluted and what refers to the reflection on their professional future, the management of economic resources and to be aware of the legal conditions on labor, who refer to take advantage of free time, little manifest in everyday life; that is to say, if there is a favorable vision for leisure and free time, but they scarcely internalize it in their daily life. Regarding men, although they indicated assigning a little more than one day to leisure and free time (average of $26.5 \%$ weekly), their vision and internalization are more attached to the freedom to do anything other than work than to recognize them as a fundamental human right and mandatory rest times within work activities. Of the 53 women, only 16 recognize it as such. 
When the variables are explored and the results analyzed, it is observed that there is a balance between individual (leisure) and individual issues with social pressure (free time); However, both moments are not fully internalized or recognized as such. For example, the issue that alludes to fundamental human rights and those recognized as obligatory within Mexican legislation. Therefore, it is concluded that extracurricular activities or that are done in leisure time and that promotes leisure, are part of what the human being is and the development trend he has. Integral education strives to reorient these constructs from a more empathic vision, since there are not a few contexts in which subjects see these activities as a waste of time. What this research throws concludes that being a right and a proactive activity, it must have an organization so that these processes can be used better.

\section{References}

CDHCU . (02 de Julio de 2019). Ley Federal del Trabajo. Recuperado el 2 de Julio de 2019, de Cámara de Diputados del H. Congreso de la Unión:

http://www.diputados.gob.mx/LeyesBiblio/pdf/ 125_020719.pdf

CDHCU. (7 de Julio de 2018). Ley General de Salud. Recuperado el 23 de Marzo de 2019, de Cámara de Diputados del H. Congreso de la Unión:

http://www.diputados.gob.mx/LeyesBiblio/pdf/ 142_241218.pdf y/o http://www.salud.gob.mx/unidades/cdi/legis/lgs /index-t3.htm

Constitución Política de los Estados Unidos Mexicanos . (2015). Artículo 4 ${ }^{\circ}$ Recuperado el 10 de Septiembre de 2018, de Secretaría de Salud:

https://www.gob.mx/salud/articulos/constitucio n-politica-de-los-estados-unidos-mexicanoarticulo-4

Cuenca, M., Bayón, F., \& Madariaga, A. (s/f). Educación y Ocio en Vitoria-Gasteiz. VitoriaGasteiz, España: Ayuntamiento de VitoriaGasteiz/Instituto de Estudios de Ocio (Universidad de Deusto). Recuperado el 25 de Enero de 2019, de https://www.vitoriagasteiz.org/wb021/http/contenidosEstaticos/adj untos/es/70/92/47092.pdf
Diccionario de la Real Academia Española. (2014). Ocio (Vigesimotercera ed.). Madrid, España. Recuperado el 3 de Enero de 2019, de https://dle.rae.es/?id=QrvsNB1

Gomes, C., \& Elizalde, R. (2009). Trabajo, tiempo libre y ocio en la contemporaneidad: Contradicciones y desafíos. Polis, Revista de la Universidad Bolivariana, 8(22). Recuperado el 25 de Noviembre de 2018, de Polis. Revista de la Univeridad Bolivariana: http://www.redalyc.org/articulo.oa?id=3051221 1015

Miranda, G. (Abril de 2006). El tiempo libre y ocio reivindicado por los trabajadores. Pasos. Revista de Turismo y Patrimonio cultural, 4(3), 301-326. doi:10.2545

Mora, C. (s/f). Derecho al esparcimiento. Acervo de la Biblioteca Jurídica Virtual del Instituto de Investigaciones Jurídicas de la UNAM. Recuperado el 14 de Julio de 2017, de https://archivos.juridicas.unam.mx/www/bjv/lib ros/6/2975/18.pdf

Munné, F. (2010). Psicología del tiempo libre. Un enfoque crítico (1a reimpresión ed., Vol. 1). México, México, México: Trillas.

OIJ. (1 de Marzo de 2008). Convención Iberoamericana de Derechos de los Jóvenes. Recuperado el 23 de Junio de 2019, de Organización Internacional de la Juventud para Iberoamérica: https://oij.org/wpcontent/uploads/2017/06/Convenci\%C3\%B3nderechos-04.pdf

ONU. (10 de Diciembre de 1948). Declaración Universal de los Derechos Humanos. Recuperado el 27 de Noviembre de 2018, de Organización de las Naciones Unidas: https://www.un.org/es/universal-declarationhuman-rights/

Sarrate, M. L. (2009). Ocio y tiempo libre en los centros educativos. Bordón. Revista de pedagogía, 60(4), 51-61. Recuperado el 2 de Diciembre de 2018, de https://dialnet.unirioja.es/descarga/articulo/291 2271.pdf 